Pemanfaatan Jurnal Online Perpustakaan BPTP Yogyakarta Dwi Titaningsih, Suharno

Kerja Sama antara SDM Perpustakaan untuk Menuju Layanan Prima dan Unggul Endang Fatmawati

Revitalisasi Peran Perpustakaan Umum bagi Masyarakat Noorika Retno Widuri

Optimalisasi Layanan Penelusuran Sumber-sumber Informasi untuk Mendukung Penulisan Karya Ilmiah Dosen dan Mahasiswa di Perguruan Tinggi Dian Hapsari

Memperkuat Peran Pustakawan dalam Mewujudkan Layanan Perpustakaan Perguruan Tinggi yang Prima dan Unggul Bambang Hermanto

Aktivitas Mahasiswa dalam Membaca Skripsi di Perpustakaan Masriyatun

Budaya Peduli dan Budaya Mutu Melayani di Perpustakaan SMP Negeri 13 Surakarta Menuju Sekolah Menyenangkan Ria Widyawati

Redesain Website UPT Perpustakaan Universitas Sebelas Maret sebagai Media Pendidikan Pengguna bagi Pemustaka Tri Hardian Satiawardana

Peran Perpustakaan dalam Membangun Citra Perpustakaan di Era Teknologi Informasi Sri Anawati

Komunitas Pustakawan Menulis (upaya menyebarluaskan dan melestarikan pengetahuan) Tri Hardiningtyas 


\section{Jurnal}

\section{Pustaka Ilmiah}

\section{Jurnal Ilmiah UPT Perpustakaan UNS}

Jurnal Pustaka Ilmiah (JPI) sebagai media kreasi para pustakawan, guru, dosen, dan praktisi dalam pengembangan profesi secara berkelanjutan. Berbagai ide dan gagasan kreatif menjadi bahan kajian yang diimplementasikan dalam berbagai model pengembangan bahan pustaka, baik cetak maupun online. Kreativitas menjadi akar pengembangan ilmu pengetahuan sepanjang hayat dengan berbagai model pengembangan budaya literasi di perpustakaan. Keindahan dan kecermatan dalam sebuah tulisan ilmiah dan nonilmiah akan dapat direalisasikan secara nyata oleh sumber daya manusia untuk menghasilkan SDM yang unggul dan kreatif dengan membaca dan menulis untuk menyinari dunia. Budaya literasi menjadi upaya untuk pengembangan dan pemberdayaan perpustakaan sebagai pusat sumber belajar untuk mendukung tri dharma perguruan tinggi.

\section{SUSUNAN REDAKSI}

Penanggung Jawab

Ketua Redaksi

Wakil Redaksi

Sekretaris

Penyunting Ahli

Penyunting

Bendahara

Sirkulasi
: Dr. Muhammad Rohmadi, M.Hum.

: Dra. Tri Hardiningtyas, M.Si.

: Haryanto, M.IP.

: Bambang Hermanto, S.Pd., M.IP., Henny Perwitosari, A.Md.

: 1. Dr. Muhammad Rohmadi, M.Hum. (Universitas Sebelas Maret);

2. Drs. Widodo, M.Soc.Sc. (Universitas Sebelas Maret);

3. Drs. Harmawan, M.Lib. (Universitas Sebelas Maret).

: Daryono, S.Sos., M.IP.; RiahWiratningsih, S.S., M.Si., Dinar Puspita Dewi, S.Sos., M.IP.; Sri Utari, S.E.

: Nurul H., A. Md.; Novi Tri Astuti, A.Md.

: Aji Hartono, A. Md.; Agus Sriyono, A.Md.; Aris Suprihadi, S.IP.

UPT PERPUSTAKAAN UNS

REDAKSI JURNAL PUSTAKA ILMIAH

Alamat: Jl. Ir. Sutami 36A Kentingan, Surakarta 57126

Telp./Fax.: (0271) 654311; email: jurnal.pustaka.ilmiah@gmail.com 


\section{Pengantar Redaksi}

\section{Salam Pustaka.}

Dengan mengucap rasa syukur kepada Allah SWT. segenap Tim Redaksi Jurnal Pustaka Ilmiah (JPI) mengucapkan banyak terima kasih kepada para penulis yang telah berkontribusi untuk penerbitan JPI volume 2 edisi Juni 2016. Penerbitan volume 2 kali ini JPI mengetengahkan tema: Pengembangan Perpustakaan menuju Layanan Prima dan Unggul. Kehadiran JPI diharapkan dapat dijadikan sebagai media penulisan bagi para pustakawan, dosen, tenaga kependidikan, guru, dan praktisi untuk menuangkan ide dan gagasan kreatifnya secara tertulis.

Dalam penerbitan JPI volume 2 bulan Juni 2016 ini disajikan sepuluh tulisan antara lain: (1) Pemanfaatan Jurnal Online Perpustakaan BPTP Yogyakarta (Dwi Titaningsih dan Suharno), (2) Kerja Sama Antara Sumber Daya Manusia Perpustakaan untuk Menuju Layanan Prima dan Unggul (Endang Fatmawati), (3) Revitalisasi Peran Perpustakaan Umum Bagi Masyarakat (Noorika Retno Widuri), (4) Optimalisasi Layanan Penelusuran Sumber-Sumber Informasi untuk Mendukung Penulisan Karya Ilmiah Dosen dan Mahasiswa di Perguruan Tinggi (Dian Hapsari), (5) Memperkuat Peran Pustakawan dalam Mewujudkan Layanan Perpustakaan Perguruan Tinggi yang Prima dan Unggul (Bambang Hemanto), (6) Aktivitas Mahasiswa dalam Membaca Skripsi di Perpustakaan FISIP-UNS (Masriyatun), (7) Budaya Peduli dan Budaya Mutu Melayani di Perpustakaan SMP Negeri 13 Surakarta Menuju Sekolah Menyenangkan (Ria Widyawati), (8) Redesain Website UPT Perpustakaan Universitas Sebelas Maret Surakarta sebagai Media Pendidikan Pengguna Bagi Pemustaka (Tri Hardian Satiawardana), (9) Peran Perpustakaan dalam Membangun Citra Perpustakaan di Era Teknologi Informasi (Sri Anawati), (10) Komunitas Pustakawan Menulis : upaya menyebarluaskan dan melestarikan pengetahuan (Tri Hardiningtyas).

Akhirnya, redaksi JPI mengucapkan banyak terima kasih kepada Kepala UPT Perpustakaan UNS yang telah memberikan dukungan dan memfasilitasi untuk penerbitan JPI. Selain itu, ucapan terima kasih juga disampaikan kepada para penulis, tim redaksi, dan Yuma Pressindo, yang telah mempersiapkan dari awal sampai terbitnya JPI. Selamat membaca.

Surakarta, Juni 2016

Ketua Redaksi 


\section{Sambutan}

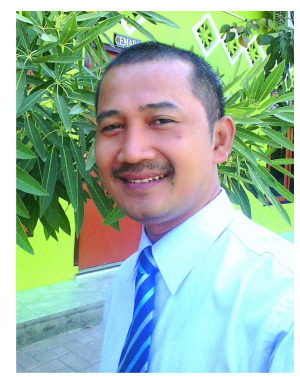

Dr. Muhammad Rohmadi, M.Hum.

\section{Kepala UPT Perpustakaan UNS}

Selamat dan sukses atas diterbitkannya kembali Jurnal Pustaka Ilmiah (JPI). Jurnal ini sebagai media kreativitas dan pengembangan softs skills para pustakawan, guru, dosen, dan praktisi untuk menuangkan ide dan gagasan demi layanan perpustakaan yang prima dan unggul. Berbagai isu terkait dengan pengembangan perpustakaan, pelayanan perpustakaan sebagai pusat sumber belajar, pendidikan, penelitian, pelestarian, dan budaya literasi akan menjadi topik-topik yang disajikan dalam jurnal ilmiah ini.

Diterbitkannya JPI sebagai bukti kepedulian UPT Perpustakaan Universitas Sebelas Maret Surakarta (UNS) dalam rangka turut berpartisipasi mengembangkan dan membudayakan literasi untuk para pustakawan dan civitas akademika di UNS maupun luar UNS. Berbagai model pengembangan softs skills menjadi alternatif untuk membekali dan memperkuat jaringan kerja sama penulisan antar kelembagaan. Dengan demikian, kerja sama antar pustakawan dan pemustaka dapat diwujudkan dengan berbagai model dalam bidang literasi.

Penerbitan JPI merupakan sarana untuk memotivasi semua pustakawan agar berkarya di bidang penulisan, baik ilmiah maupun nonilmiah. Para pustakawan harus menjadi pionir dalam bidang penulisan. Hal ini sebagai bentuk kepedulian dan keteladaan para pustakawan yang memproses, menyajikan, dan menikmati bahan-bahan pustaka cetak dan noncetak di perpustakaan. Ketersedian bahan pustaka akan menjadi bahan paling nyata untuk dikembangkan dalam berbagai model perwujudan teknik penulisan. Hal terpenting yang harus dimiliki oleh para pustakawan adalah semangat untuk berbagi pengetahuan melalui tulisan.

Kepedulian setiap sumber daya manusia kepada kelembagaan dapat dituangkan dalam berbagai model pengabdian, salah satunya adalah melalui tulisan. Berbagai ide dan gagasan dapat direalisasikan dengan berbagai model bentuk artikel jurnal, buku, modul, monograf, dan lain sebagainya. Para civitas akademika, guru, praktisi harus memiliki keterampilan menulis sebagai bentuk perwujudan pengembangan diri secara berkelanjutan. Berbagai tulisan dan referensi sudah disajikan tetapi masih sangat minim untuk diimplementasikan dalam kehidupan. Banyak orang pandai dalam berbicara tetapi masih sedikit yang menuangkan ide dan gagasannya dalam bentuk tulisan.

Akhirnya, keluarga besar UPT Perpustakaan UNS mengucapkan banyak terima kasih kepada Rektor, Wakil Rektor, pengelola JPI, penulis, dan semua pihak yang telah mendukung penerbitan JPI. Semoga dengan diterbitkannya JPI ini dapat menjadi media untuk menulis para pustakawan, dosen, guru, dan praktisi dalam bidang iptek dan seni. Ucapan terima kasih juga diucapkan kepada percetakan Yuma Pressindo yang telah membantu mempersiapkan dari awal sampai terbitnya JPI ini. Akhirnya, semoga JPI dapat memberikan nilai kemaslahatan untuk umat. 


\section{DAFTAR ISI}

\section{JURNAL PUSTAKA ILMIAH EDISI KEDUA: VOLUME 1 NOMOR 2/ JUNI 2016}

\section{Tema: Pengembangan Perpustakaan Menuju Layanan Prima dan Unggul}

Pemanfaatan Jurnal Online Perpustakaan BPTP Yogyakarta

Dwi Titaningsih, Suharno

Kerja Sama antara SDM Perpustakaan untuk Menuju Layanan Prima dan Unggul

Endang Fatmawati

Revitalisasi Peran Perpustakaan Umum bagi Masyarakat.

Noorika Retno Widuri

Optimalisasi Layanan Penelusuran Sumber-sumber Informasi untuk Mendukung Penulisan Karya Ilmiah Dosen dan Mahasiswa di Perguruan Tinggi..

Dian Hapsari

Memperkuat Peran Pustakawan dalam Mewujudkan Layanan Perpustakaan Perguruan Tinggi yang Prima dan Unggul.

Bambang Hermanto

Aktivitas Mahasiswa dalam Membaca Skripsi di Perpustakaan

Masriyatun

Budaya Peduli dan Budaya Mutu Melayani di Perpustakaan SMP Negeri 13 SurakartaMenuju SekolahMenyenangkan.

Ria Widyawati

Redesain Website UPT Perpustakaan Universitas Sebelas Maret sebagai Media Pendidikan Pengguna bagi Pemustaka.

Tri Hardian Satiawardana

Peran Perpustakaan dalam Membangun Citra Perpustakaan di Era Teknologi Informasi

Sri Anawati

Komunitas Pustakawan Menulis (upaya menyebarluaskan dan melestarikan pengetahuan)

Tri Hardiningtyas 


\title{
AKTIVITAS MAHASISWA DALAM MEMBACA SKRIPSI DI PERPUSTAKAAN FISIP UNS
}

\author{
Masriyatun \\ Universitas Sebelas Maret Surakarta \\ Email: masriyatun@yahoo.com
}

\begin{abstract}
Libraries in general most people say that as a place to read and borrow library collections, where the librarian or library manager provides various types of services. Services that can be said to be superior and excellent, in the library Fisip UNS contained in the reference collection service because the place is never empty by the reader. Readers in this space the average reader of scientific work, such as theses and other types of research. The purpose of writing this article to determine the activity of students in reading thesis. Activities of students in reading this paper are used to meet the information needs in the manufacture of scientific work. This research method using descriptive method. Location of the study in the library Fisip UNS. The results of this study indicate that the activity of students in reading thesis categorized quite high as 30 or $60 \%$ of respondents said it was.
\end{abstract}

Keywords: student activities, reading, essay

\begin{abstract}
ABSTRAK
Perpustakaan pada umumnya sebagian besar orang mengatakan bahwa sebagai tempat untuk membaca dan meminjam koleksi bahan pustaka, di mana pustakawan atau pengelola perpustakaan menyediakan berbagai jenis layanan. Layanan yang dapat dikatakan unggul dan prima, di perpustakaan Fisip UNS terdapat di layanan koleksi referensi karena tempat ini tidak pernah sepi oleh pembaca. Pembaca di ruang ini ratarata pembaca karya ilmiah, seperti skripsi dan jenis penelitian lainnya. Tujuan penulisan artikel ini untuk mengetahui aktivitas mahasiswa dalam membaca skripsi. Aktivitas mahasiswa dalam membaca skripsi ini digunakan untuk pemenuhan kebutuhan informasi dalam pembuatan karya ilmiah. Metode penelitian ini menggunakan metode deskriptif. Lokasi penelitian di perpustakaan Fisip UNS. Hasil penelitian ini menunjukkan bahwa aktivitas mahasiswa dalam membaca skripsi dikategorikan cukup tinggi karena 30 atau $60 \%$ responden menyatakan sedang.
\end{abstract}

Kata kunci: aktivitas mahasiswa, membaca dan skripsi

\section{PENDAHULUAN}

Membaca merupakan kebutuhan mahasiswa yang harus dilakukan untuk bisa meningkatkan pengetahuan maupun wawasannya dalam memenuhi tugas di bidang akademiknya sebagai mahasiswa. Tuntutan referensi yang harus dipenuhi dalam menunjang karya ilmiahnya sebagai mahasiswa mau tidak mau harus membaca, lebih-lebih mereka yang studinya sudah tahap akhir jenjang. Hal ini yang menumbuhkan aktivitas dalam membaca koleksi referensi khususnya mengenai karya ilmiah seperti skripsi. Dalam membaca koleksi skripsi, umumnya mereka tidak hanya membaca sebanyak dua atau tiga buku dalam setiap kali baca di meja baca ruang referensi perpustakaan 
Fisip UNS untuk dijadikan perbandingan sebagai bahan referensi di bahan pembuatan skripsinya. Hal ini tentunya referensi yang sesuai dengan informasi yang dibutuhkannya.

Banyaknya mahasiswa yang melakukan kegiatan membaca di ruang koleksi referensi inilah yang membuat penulis untuk menjadikannya sebagai bahan kajian dalam artikel ini. Kegiatan mahasiswa dalam membaca koleksi skripsi dapat dilihat pada gambar berikut ini:

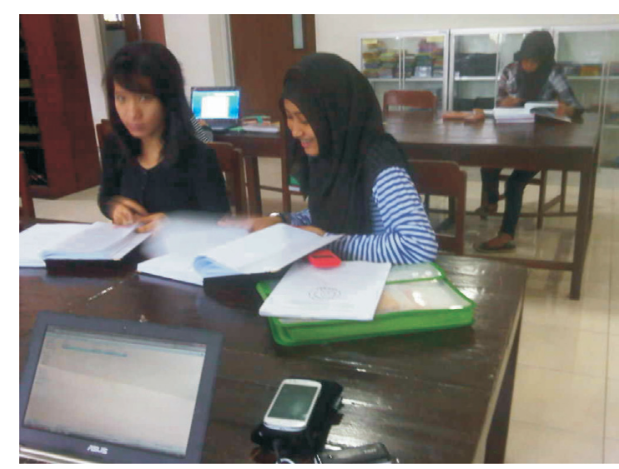

Gambar 1 Pembaca Skripsi

(Sumber: Perpustakaan Fisip UNS)

Seperti yang terlihat pada gambar di atas, berdasarkan hasil pengamatan penulis, pada umumnya setelah membaca, sebagian mahasiswa banyak yang mengetiknya langsung menggunakan komputer pribadinya untuk mengambil informasi yang dibutuhkannya. Akan tetapi, tidak jarang pula yang hanya membaca saja karena masih banyak acuanacuan lagi yang harus benar-benar sesuai dengan informasi yang dibutuhkannya. Informasi atau bahan bacaan yang ada di dalam koleksi referensi, khususnya skripsi pada umumnya masih banyak yang harus dicermati apakah sistem penulisan, seperti ejaan yang digunakan, kutipan yang dilakukan, sumber yang digunakan, sudah sesuai dengan yang dikehendakinya. Hal inilah yang membuat pembaca menjadi lebih banyak membaca referensi dibutuhkanuntuk memenuhi kebutuhan informasi bagi penulisan karya ilmiahnya. Dalam mengambil informasi dari karya ilmiah lain, harus benar-benar karya ilmiah yang bisa mendukung karya ilmiah yang akan ditulisnya.

Beragamnya kebutuhan informasi yang harus dicari selain dalam hal sistem penulisan, ada juga kebutuhan informasi lainnya, seperti teori yang digunakan, metodologi, hasil penelitian terdahulu, bahkan jurnal lokal maupun internasional yang benar-benar sesuai dengan kebutuhan guna mendukung karya ilmiah yang dibuatnya. Dalam kesehariannya, mereka rata-rata berkunjung di perpustakaan, khususnya di ruang koleksi referensi sebanyak tiga kali dalam seminggu karena mereka ratarata tinggal fokus di mata kuliah skripsi.

Berdasarkan hal tersebut, rumusan masalah artikel ini adalah bagaimana aktivitas mahasiswa dalam membaca skripsi di ruang koleksi referensi Perpustakaan Fisip UNS periode 1 Februari - Maret 2014?

\section{METODE PENELITIAN}

Metode penelitian yang digunakan dalam kajian survei ini adalah metode deskriptif. Penelitian ini dilakukan dengan cara survei. Lokasi dalam penelitian ini adalah Perpustakaan Fisip UNS. Populasi dalam penelitian ini adalah mahasiswa yang membaca koleksi referensi skripsi selama satu bulan, di mana setiap harinya ada 25 orang, dalam satu minggu 125 orang, sehingga populasi dalam penelitian ini sejumlah 500 orang. Sampel dalam penelitian ini adalah mahasiswa yang membaca koleksi referensi skripsi di perpustakaan Fisip UNS periode bulan Februari - Maret 2014 yang penulis ambil sebanyak $10 \%$ dari anggota populasi. Jadi, jumlah sampel dalam penelitian ini sebanyak 50 orang.

Ada pun sumber data yang peneliti gunakan dalam penelitian ini adalah data primer dan sekunder. Sedangkan teknik pengumpulan datanya menggunakan studi lapangan (field research), yaitu pengumpulan data yang meliputi kegiatan survei di lokasi penelitian 
melalui pengamatan (observasi), kuesioner, wawancara dan dokumentasi, serta studi pustaka (library research). Data yang diperoleh dari hasil penelitian akan dianalisis menggunakan Analisis Tabel Tunggal yang dilakukan dengan membagi-bagikan variabel penelitian ke dalam kategori-kategori yang dilakukan atas dasar frekuensi melalui SPSS 17.00. Tabel Tunggal merupakan langkah awal dalam menganalisis data yang terdiri dari kolom-kolom, yaitu frekuensi dan persentase untuk setiap kategori (Effendi, 2001).

\section{HASIL DAN PEMBAHASAN}

Aktivitas mahasiswa dalam membaca skripsi ini diukur melalui indikator berikut ini.

1. Pernah tidaknya responden membaca skripsi.

2. Tingkat keseringan responden datang ke ruang koleksi referensi perpustakaan.

3. Motivasi responden dalam membaca skripsi.

4. Frekuensi responden dalam membaca skripsi.

5. Intensitas responden dalam membaca skripsi.

6. Lama responden dalam membaca skripsi.

7. Tingkat perhatian responden pada saat membaca skripsi.

8. Tingkat keseriusan responden pada saat membaca skripsi.

9. Tingkat keikutsertaan responden dalam membaca skripsi.

10. Tingkat ketergantungan responden dalam membaca skripsi.

Selanjutnya, hasil dan pembahasan secara detail dapat diketahui melalui penjelaan berikut ini.

\section{Pernah Tidaknya Responden Membaca Skripsi}

Untuk mengetahui lebih jelas mengenai pernah tidaknya responden membaca skripsi di ruang koleksi referensi Perpustakaan Fisip UNS, dapat dlihat pada tabel berikut ini :

\begin{tabular}{|c|c|c|c|}
\hline No. & $\begin{array}{c}\text { Jawaban } \\
\text { Responden }\end{array}$ & Frekuensi & $\begin{array}{c}\text { Persentase } \\
(\%)\end{array}$ \\
\hline 1. & Pernah & 30 & 60,0 \\
\hline 2. & $\begin{array}{c}\text { Kadang- } \\
\text { kadang }\end{array}$ & 20 & 40,0 \\
\hline 3. & Tidak pernah & 0 & 08,0 \\
\hline & Jumlah & 50 & 100,0 \\
\hline
\end{tabular}

Tabel 1 Pernah Tidaknya Responden Membaca Skripsi

Berdasarkan tabel di atas, dapat diketahui bahwa responden yang mengatakan pernah membaca skripsi di ruang kolekesi referensi perpustakaan Fisip UNS sebanyak 30 orang atau 60,0\%. Sedangkan yang menjawab kadang-kadang sebanyak 20 orang atau 40,0\%. Jadi, dapat dikatakan bahwa sebagian besar responden menyatakan pernah membaca skripsi di ruaang koleksi referensi perpustakaan Fisip UNS.

\section{Tingkat Keseringan Responden Datang ke Ruang Koleksi Referensi Perpustakaan}

Sedangkan untuk mengetahui lebih jelasnya mengenai tingkat keseringan responden datang ke ruang koleksi referensi Perpustakaan Fisip UNS dalam satu minggu, dapat dilihat pada tabel berikut ini:

\begin{tabular}{|c|c|c|c|}
\hline No. & $\begin{array}{c}\text { Jawaban } \\
\text { Responden }\end{array}$ & Frekuensi & $\begin{array}{c}\text { Persentase } \\
(\%)\end{array}$ \\
\hline 1. & $\begin{array}{l}3 \text { kali dalam } \\
\text { seminggu }\end{array}$ & 31 & 62,0 \\
\hline 2. & $\begin{array}{l}2 \text { kali dalam } \\
\text { seminggu }\end{array}$ & 16 & 32,0 \\
\hline 3. & $\begin{array}{l}1 \text { kali dalam } \\
\text { seminggu . }\end{array}$ & 3 & 06,0 \\
\hline & Jumlah & 50 & 100,0 \\
\hline
\end{tabular}

Tabel 2 Tingkat Keseringan Responden Datang ke Perpustakaan Fisip UNS

Berdasarkan tabel di atas, dapat diketahui bahwa responden yang menyatakan pernah datang ke ruang koleksi referensi Perpustakaan Fisip UNS sebanyak 3 kali dalam seminggu 
sejumlah 31 orang atau 62,0\%. Sedangkan yang datang sebanyak 2 kali dalam seminggu sejumlah 16 orang atau 32,0\%. Jadi dalam hal ini, dapat dikatakan bahwa sebagian besar responden menyatakan pernah datang ke ruang koleksi referensi Perpustakaan Fisip UNS sebanyak 3 kali dalam seminggu.

\section{Motivasi Responden dalam Membaca Skripsi}

Untuk mengetahui lebih jelas mengenai motivasi responden dalam membaca skripsi di ruang koleksi referensi Perpustakaan Fisip UNS, dapat dilihat pada tabel berikut ini:

\begin{tabular}{|c|c|c|c|}
\hline No. & $\begin{array}{c}\text { Jawaban } \\
\text { Responden }\end{array}$ & Frekuensi & $\begin{array}{c}\text { Persentase } \\
(\%)\end{array}$ \\
\hline 1. & $\begin{array}{c}\text { Untuk } \\
\text { menambah } \\
\text { pengetahuan } \\
\text { mengenai } \\
\text { bentuk jenis- } \\
\text { jenis karya } \\
\text { ilmiah. }\end{array}$ & 22 & 44,0 \\
\hline 2. & $\begin{array}{c}\text { Untuk sekadar } \\
\text { menambah } \\
\text { pengetahuan. }\end{array}$ & 24 & 48,0 \\
\hline 3. & $\begin{array}{c}\text { Untuk mengisi } \\
\text { waktu luang } \\
\text { kuliah . }\end{array}$ & 4 & 8,0 \\
\hline & Jumlah & 50 & 100,0 \\
\hline
\end{tabular}

Tabel 3 Motivasi Responden dalam Membaca

Skripsi di Ruang Koleksi Referensi

Perpustakaan Fisip UNS

Berdasarkan tabel di atas, dapat diketahui bahwa responden yang menyatakan untuk menambah pengetahuan mengenai bentuk jenis-jenis karya ilmiah sebanyak 22 orang atau $44,0 \%$. Sedangkan yang menyatakan untuk sekadar menambah pengetahuan sebanyak 24 orang atau 48,0\%. Jadi, dapat dikatakan bahwa sebagian besar responden menyatakan motivasi dalam membaca skripsi di ruang koleksi referensi Perpustakaan Fisip UNS sekadar menambah pengetahuan yang menyangkut dengan tulisannya.

\section{Frekuensi Responden dalam Membaca Skripsi}

Untuk mengetahui lebih jelas mengenai frekuensi responden dalam membaca skripsi, dapat dilihat pada tabel berikut ini:

\begin{tabular}{|c|c|c|c|}
\hline No. & $\begin{array}{c}\text { Jawaban } \\
\text { Responden }\end{array}$ & Frekuensi & $\begin{array}{c}\text { Persentase } \\
(\%)\end{array}$ \\
\hline 1. & $\begin{array}{c}\text { Membaca } \\
\text { skripsi 12 x } \\
\text { dalam 1 bulan. }\end{array}$ & 32 & 64,0 \\
\hline 2. & $\begin{array}{c}\text { Membaca } \\
\text { skripsi 8-10x } \\
\text { dalam 1bulan. }\end{array}$ & 15 & 30,0 \\
\hline $\begin{array}{c}\text { Membaca } \\
\text { skripsi 4-6 x } \\
\text { dalam 1 bulan. }\end{array}$ & 3 & 6,0 \\
\hline & Jumlah & 50 & 100,0 \\
\hline
\end{tabular}

Tabel 4 Frekuensi Responden dalam

Membaca Skripsi di Ruang Koleksi Referensi Perpustakaan Fisip UNS

Berdasarkan tabel di atas, dapat diketahui bahwa responden yang menyatakan membaca dengan menggunakan waktu khusus sebanyak 23 orang atau $46,0 \%$. Sedangkan yang menyatakan membaca dengan menggunakan waktu luang juga sebanyak 23 orang atau 46,0\%. Jadi, dapat dikatakan bahwa antara responden yang membaca skripsi dengan menggunakan waktu khusus dan waktu luang mempunyai jumlah yang sama besarnya.

\section{Intensitas Responden dalam Membaca Skripsi}

Untuk mengetahui lebih jelas mengenai intensitas responden dalam membaca skripsi, dapat dilihat pada tabel berikut ini: 


\begin{tabular}{|c|c|c|c|}
\hline No. & $\begin{array}{c}\text { Jawaban } \\
\text { Responden }\end{array}$ & Frekuensi & $\begin{array}{c}\text { Persentase } \\
(\%)\end{array}$ \\
\hline 1. & $\begin{array}{c}\text { Membaca } \\
\text { dengan } \\
\text { menggunakan } \\
\text { waktu khusus }\end{array}$ & 23 & 46,0 \\
\hline 2. & $\begin{array}{c}\text { Membaca } \\
\text { dengan } \\
\text { menggunakan } \\
\text { waktu luang }\end{array}$ & 23 & 46,0 \\
\hline 3. & $\begin{array}{c}\text { Membaca bila } \\
\text { butuh saja }\end{array}$ & 4 & 8,0 \\
\hline & Jumlah & 50 & 100,0 \\
\hline
\end{tabular}

Tabel 5 Intensitas Responden dalam Membaca Skripsi

Berdasarkan tabel di atas, dapat diketahui bahwa responden yang menyatakan membaca dengan menggunakan waktu khusus sejumlah 23 orang atau 46,0\%. Sedangkan yang membaca dengan menggunakan waktu luang sejumlah 23 orang juga atau $46 ., 0 \%$ dan yang menyatakan membaca apabila butuh saja sejumlah 4 orang atau $8,0 \%$.

\section{Lama Responden dalam Membaca Skripsi}

Untuk mengetahui lebih jelas mengenai lama responden dalam membaca skripsi, dapat dilihat pada tabel berikut ini:

\begin{tabular}{|c|c|c|c|}
\hline No. & $\begin{array}{c}\text { Jawaban } \\
\text { Responden }\end{array}$ & Frekuensi & $\begin{array}{c}\text { Persentase } \\
(\%)\end{array}$ \\
\hline 1. & $\begin{array}{c}\text { Sampai dengan } \\
60 \text { menit }\end{array}$ & 30 & 60,0 \\
\hline 2. & $\begin{array}{c}\text { Sampai dengan } \\
30 \text { menit }\end{array}$ & 17 & 34,0 \\
\hline 3. & $\begin{array}{c}\text { Sampai dengan } \\
10 \text { menit }\end{array}$ & 3 & 6,0 \\
\hline & Jumlah & 50 & 100,0 \\
\hline
\end{tabular}

Tabel 6 Lama Responden dalam Membaca Per Skripsi

Berdasarkan tabel di atas, dapat dikatakan bahwa responden yang menyatakan lama membaca per skripsi sampai dengan 60 menit sebanyak 30 orang atau 60,0\%. Sedangkan yang menyatakan membaca sampai dengan 30 menit sebanyak 17 orang atau 34,0\%. Jadi, dalam hal ini dapat dikatakan bahwa sebagian besar responden menyatakan rata-rata dalam membaca skripsi lamanya sampai dengan 60 menit per skripsi.

\section{Tingkat Perhatian Responden pada Saat Membaca Skripsi}

Untuk mengetahui lebih jelas mengenai tingkat perhatian responden pada saat membaca skripsi, dapat dilihat pada tabel berikut ini:

\begin{tabular}{|c|c|c|c|}
\hline No. & $\begin{array}{c}\text { Jawaban } \\
\text { Responden }\end{array}$ & Frekuensi & $\begin{array}{c}\text { Persentase } \\
(\%)\end{array}$ \\
\hline 1. & $\begin{array}{c}\text { Membaca } \\
\text { tanpa diselingi } \\
\text { aktivitas lain }\end{array}$ & 22 & 44,0 \\
\hline 2. & $\begin{array}{c}\text { Membaca } \\
\text { dengan } \\
\text { diselingi } \\
\text { aktivitas lain }\end{array}$ & 22 & 44,0 \\
\hline 3. & $\begin{array}{c}\text { Membaca } \\
\text { sepintas saja }\end{array}$ & 6 & 12,0 \\
\hline & $\begin{array}{c}\text { Jumlah } \\
\text { Tumb }\end{array}$ & 50 & 100,0 \\
\hline
\end{tabular}

Tabel 7 Tingkat Perhatian Responden pada Saat Membaca Skripsi

Berdasarkan tabel di atas, dapat dikatakan bahwa responden yang menyatakan perhatiannya pada saat membaca skripsi tanpa diselingi aktivitas lain sebanyak 22 orang atau $44,0 \%$. Sedangkan yang membaca dengan diselingi aktivitas lain sebanyak 22 orang atau 44,0\% juga. Jadi, dalam hal ini dapat dikatakan bahwa antara responden yang membaca tanpa diselingi aktivitas lain dengan yang membaca dengan diselingi aktivitas lain mempunyai jumlah yang sama tinggi.

\section{Tingkat Keseriusan Responden pada Saat Membaca Skripsi}

Untuk mengetahui lebih jelasnya mengenai tingkat keseriusan responden pada saat membaca skripsi, dapat dilihat pada tabel berikut ini: 


\begin{tabular}{|c|l|c|c|}
\hline No. & $\begin{array}{c}\text { Jawaban } \\
\text { Responden }\end{array}$ & Frekuensi & $\begin{array}{c}\text { Persentase } \\
(\%)\end{array}$ \\
\hline 1. & Serius & 29 & 58,0 \\
\hline 2. & Cukup serius & 17 & 34,0 \\
\hline 3. & Kurang serius & 4 & 8,0 \\
\hline & Jumlah & 50 & 100,0 \\
\hline
\end{tabular}

Tabel 8 Tingkat Keseriusan Responden pada Saat Membaca Skripsi

Berdasarkan tabel di atas, dapat diketahui bahwa responden yang menyatakan serius pada saat membaca skripsi sebanyak 29 orang atau $58,0 \%$. Sedangkan yang menyatakan cukup serius sebanyak 17 orang atau 34,0\%. Jadi, dalam ini dapat dikatakan bahwa sebagian besar responden menyatakan serius pada saat membaca skripsi di ruang koleksi referensi Perpustakaan Fisip UNS.

\section{Tingkat Keikutsertaan Responden dalam Membaca Skripsi}

Untuk mengetahui lebih jelasnya mengenai tingkat keikutsertaan responden pada saat membaca skripsi, dapat dilihat pada tabel berikut ini:

\begin{tabular}{|c|c|c|c|}
\hline No. & $\begin{array}{c}\text { Jawaban } \\
\text { Responden }\end{array}$ & Frekuensi & $\begin{array}{c}\text { Persentase } \\
(\%)\end{array}$ \\
\hline 1. & $\begin{array}{c}\text { Selalu } \\
\text { mengikuti } \\
\text { sampai dengan } \\
\text { terbitan } \\
\text { terbaru }\end{array}$ & 22 & 44,0 \\
\hline & $\begin{array}{c}\text { Kadang- } \\
\text { kadang } \\
\text { mengikuti } \\
\text { sampai dengan } \\
\text { terbitan } \\
\text { terbaru }\end{array}$ & 24 & 48,0 \\
\hline 3. & $\begin{array}{c}\text { Tidak pernah } \\
\text { mengikuti } \\
\text { sampai dengan } \\
\text { terbitan } \\
\text { terbaru }\end{array}$ & 4 & 8,0 \\
\hline & Jumlah & 50 & 100,0 \\
\hline
\end{tabular}

Tabel 9 Tingkat Keikutsertaan Responden pada Saat Membaca Skripsi
Berdasarkan tabel di atas, dapat diketahui bahwa responden yang menyatakan tingkat keikutsertaannya pada saat membaca skripsi dengan menjawab selalu mengikuti sampai dengan terbitan terbaru sejumlah 22 orang atau $44,0 \%$. Sedangkan yang menyatakan kadangkadang sebanyak 20 orang atau 40,0\%. Jadi, dalam hal ini dapat dikatakan bahwa sebagian besar responden menyatakan selalu mengikuti sampai dengan terbitan terbaru dalam membaca skripsi di ruang koleksi referensi Perpustakaan Fisip UNS.

\section{Tingkat Ketergantungan Responden dalam Membaca Skripsi}

Untuk mengetahui lebih jelas mengenai tingkat ketergantungan responden pada saat membaca skripsi yang dibaca, dapat dilihat pada tabel berikut ini:

\begin{tabular}{|c|c|c|c|}
\hline No. & $\begin{array}{c}\text { Jawaban } \\
\text { Responden }\end{array}$ & Frekuensi & $\begin{array}{c}\text { Persentase } \\
(\%)\end{array}$ \\
\hline 1. & $\begin{array}{c}\text { Sangat tergantung } \\
\text { karena sangat } \\
\text { membutuhkan }\end{array}$ & 26 & 52,0 \\
\hline 2. & $\begin{array}{c}\text { Tergantung } \\
\text { karena } \\
\text { membutuhkan }\end{array}$ & 20 & 40,0 \\
\hline 3. & $\begin{array}{c}\text { Cukup } \\
\text { tergantung karena } \\
\text { tidak begitu } \\
\text { membutuhkan } \\
\text { sekali }\end{array}$ & 4 & 8,0 \\
\hline & Jumlah & 50 & 100,0 \\
\hline
\end{tabular}

Tabel 10 Tingkat Ketergantungan Responden pada Saat Membaca Skripsi

Berdasarkan tabel di atas, dapat diketahui bahwa tingkat ketergantungan responden pada saat membaca skripsi yang menyatakan sangat tergantung karena sangat membutuhkan sebanyak 26 orang atau 52,0\%. Sedangkan yang menyatakan tergantung karena membutuhkan sebanyak 20 orang atau 40,0\%. Jadi, dalam hal ini dapat dikatakan bahwa sebagian besar responden menyatakan sangat tergantung karena sangat membutuhkan. 


\section{Hasil Analisis}

Berdasarkan penjelasan variabel di atas, untuk mencari kategori variabel aktivitas mahasiswa dalam membaca skripsi di Perpustakaan Fisip UNS dapat dikatakan tinggi, sedang, dan rendah dapat dicari melalui :

Interval kelas $=\frac{\text { Nilai_tertinggi - Nilai_terendah }}{\text { Jumlah_kelas }}$

$$
I=\frac{30-16}{3}=\frac{14}{3}=4,6=5
$$

Ada pun variabel aktivitas mahasiswa dalam membaca skripsi di ruang koleksi referensi Perpustakaan Fisip UNS dapat dikategorikan sebagai berikut:

a. Tinggi bila responden menjawab a dengan nilai 3.

b. Sedang bila responden menjawab b dengan nilai 2.

c. Rendah bila responden menjawab c dengan nilai 1 .

Untuk menentukan kategori variabel aktivitas mahasiswa dalam membaca skripsi di ruang koleksi referensi Perpustakaan Fisip UNS tersebut, dapat dijelaskan dalam perhitungan berikut ini:

a. Kategori Tinggi dengan nilai $26-30$

b. Kategori Sedang dengan nilai $21-25$

c. Kategori Rendah dengan nilai $16-20$

Selanjutnya, untuk mengetahui tabel frekuensi variabel aktivitas mahasiswa dalam membaca skripsi, dapat dilihat pada tabel berikut ini:

\begin{tabular}{|l|l|c|c|}
\hline No. & $\begin{array}{c}\text { Jawaban } \\
\text { Responden }\end{array}$ & Frekuensi & $\begin{array}{c}\text { Persentase } \\
(\%)\end{array}$ \\
\hline 1. & Tinggi & 16 & 32,0 \\
\hline 2. & Sedang & 30 & 60,0 \\
\hline 3. & Rendah & 4 & 8,0 \\
\hline & Jumlah & 50 & 100,0 \\
\hline
\end{tabular}

Tabel 11 Distribusi Frekuensi Variabel Aktivitas Mahasiswa dalam Membaca Skripsi di Ruang Koleksi Referensi Perpustakaan Fisip UNS
Berdasarkan tabel di atas, dapat diketahui bahwa responden yang menyatakan variabel aktivitas mahasiswa dalam membaca skripsi di ruang koleksi referensi Perpustakaan Fisip UNS mempunyai kategori tinggi sebanyak 16 orang atau $32,0 \%$. Sedangkan yang menyatakan mempunyai kategori sedang sebanyak 30 orang atau $60,0 \%$ dan yang menyatakan rendah sebanyak 4 orang atau $8,0 \%$. Jadi, dapat disimpulkan bahwa Variabel aktivitas mahasiswa dalam membaca skripsi di ruang koleksi referensi Perpustakaan Fisip UNS mempunyai kategori cukup tinggi atau sedang.

\section{PENUTUP}

Berdasarkan dari hasil pembahasan dan analisis data di atas melalui program SPSS for 18.00 yang terdapat pada tabel distribusi frekuensi variabel aktivitas mahasiswa dalam membaca skripsi di ruang koleksi referensi Perpustakaan Fisip UNS, dapat dinyatakan kategori cukup tinggi karena 30 responden atau $60 \%$ responden menyatakan sedang. Hal ini disebabkan cukup banyaknya mahasiswa yang membaca skripsi di ruang koleksi referensi perpustakaan Fisip UNS.

Untuk lebih meningkatkan aktivitas mahasiswa dalam membaca skripsi di Perpustakaan Fisip UNS, perlu selalu memperbaharui atau mengganti koleksinya dengan menyajikan terbitan skripsi yang baru setiap periode. 


\section{DAFTAR PUSTAKA}

Effendi, Sofian dan Singarimbun, Masri. 2001. Metode Penelitian Survei. Jakarta: LP3ES.

Jalaludin, Rakhmat Jalaludin. 2004. Metode Penelitian Komunikasi. Bandung : PT Remadja Rosdakarya.

Maria Agustina S. (Ed.). 2010. SPSS 18. Jakarta: Andi.

Slamet, Y.. 1993. Analisa Kuantitatif Data Sosial. Surakarta: Dabara Publisher. 